\title{
Yönetim Sürecinde Otorite Kullanımı ve Ortaya Çıkan Sorunların Değerlendirilmesi: Eleştirel Bir Yaklaşım ${ }^{1}$
}

\author{
Salih ARSLAN ${ }^{*}$
}

ÖZ

$\mathrm{Bu}$ çalışmanın amacı yönetim sürecinde otoritenin rolünü, etkisini ve ortaya çıkardığı sorunları eleştirel bir bakış açısıyla tartışmaktır. Önce otorite kavramının sosyal bilimler alanındaki yeri değerlendirilmiş daha sonra yönetim sürecindeki rolü ve etkisine yer verilmiştir. Otorite kavramı sadece yönetim alanındaki işlevsel yönüyle değil; psikolojik, toplumsal, politik ve felsefi yönlerini de kapsayacak ölçüde geniş anlamıyla ele alınmıştır. Onun yönetim sürecindeki kullanımıyla ortaya çıkan sorunların sadece yönetimsel sorunlar olmadığı vurgulanmış ve ortaya çıkan insani sorunlara dikkat çekilmiştir. Bu nedenle yönetim sürecinde uygulanan bütün otorite tiplerinin yanında ahlaki bir otoriteye de ihtiyaç olduğu değerlendirilmiştir. Kamu işyerlerinde otorite algısı üzerine anket çalışması yapılmış ve sonuçlar teorik değerlendirmelerle karşılaştırılarak teori pratik uyumu yorumlanmaya çalışılmıştır.

Anahtar Kelimeler: Yönetim, Otorite, Otorite Sorunları, Ahlaki Otorite

JEL Sinıflandırması: M10

\section{The Usage of Authority in Management Process and Evaluation of Emerged Problems: A Critical Approach}

\begin{abstract}
This study aims to discuss the role, effect and the problems of 'authority' in the management process from a critical perspective. Firstly, the concept of authority is evaluated as a term in social science, then the role and effect of authority in management process is emphasized. The concept of authority is discussed not only in terms of its practical issues in management discipline but also the psychological, political and philosophical aspects of the term are included in discussion. Therefore, it is underlined that the usage of authority causes not only managerial problems but also some humane issues. So, the study professes that a moral authority is required besides other types of authority in management process. In this context, the study aims to test the accordance between theory and practice by comparing the results of the survey, which is implemented on public officers about their perception of authority, with the theoretical discussions.
\end{abstract}

Keywords: Management, Authority, Authority Problems, Moral Authority

JEL Classification: M10

Geliş Tarihi / Received: 27.03.2017 Kabul Tarihi / Accepted: 12.07.2017

\footnotetext{
${ }^{1} \mathrm{Bu}$ çalışma, Pamukkale Üniversitesi Sosyal Bilimler Enstitüsü'nde Prof. Dr. Feyzullah Eroğlu danışmanlığında yüksek lisans tezi olarak hazırlanan ve 2009 yılında kabul edilen "Yönetim Faaliyetlerini Harekete Geçiren Güç Olarak Otorite Kullanımı, Ortaya Çıkan Sorunlar, Çözüm Önerileri ve Çorum İlinde Faaliyet Gösteren İş Örgütlerinde Bir Araştırma" adlı tezden türetilmiştir.

* Öğr. Gör., Bilecik Şeyh Edebali Üniversitesi, Osmaneli Meslek Yüksekokulu, Yönetim ve Organizasyon Bölümü, salih.arslan@ bilecik.edu.tr, https://orcid.org/0000-0002-4993-5611
} 


\section{GİRIŞ}

Yönetim faaliyeti geçmişe nazaran oldukça karmaşıklaşmış görünse de merkezinde hala sevk ve idare etme eylemi vardır. "Otorite" kavramı da bu eylemin temel itici gücü olarak etkinliğini ve geçerliliğini korumaktadır. Otorite, yönetim faaliyetinin özünü teşkil eden bir faktör olarak kullanımındaki hatalar ya da kullanıcısının farklı amaçları nedeniyle birçok yönetim sorununa neden olabilmektedir. $\mathrm{Bu}$ sorunlar hem yönetilenlere hem de yönetimin etkinliğine olumsuz yansımaktadır. Bu çalışma; otorite kavramını felsefe, sosyoloji, siyaset ve yönetim bilimi açısından incelemeyi, otoritenin diğer benzer kavramlarla yakınlık ve farklılıklarını ortaya koymayı, otoritenin yönetim süreçlerindeki önemi ve rolünü açıklamayı, yönetim süreçlerindeki otorite kaynaklı sorunları tespit etmeyi ve bu sorunların nasıl üstesinden gelinebileceğine dair bazı değerlendirmeler yapmayı amaçlamaktadır. Bu amaçla otorite kavramına ilişkin literatür incelenerek teorik olarak kavramsal çerçeve oluşturulmaya çalışılmıştır. Daha sonra kamu işyerlerinde otoritenin yönetim süreçlerindeki rolü ve etkisine ilişkin anket uygulaması yapılmış, anket verilerinden elde edilen bulgularla teorik değerlendirmeler karşılaştırılarak yönetim - otorite ilişkisi, otoritenin kullanımından kaynaklanan sorunlar ve yönetim temelinde çözüm önerileri tartış1lmıştır.

\section{KAVRAMSAL ÇERÇEVE}

Türkiye'de otorite ve yönetim ilişkisine dair bazı araştırmalara rağmen otoritenin yönetim sürecinde meydana getirdiği sorunlara ve bu sorunların giderilmesine ilişkin alternatif çözüm önerilerine ilişkin pek fazla çalışmaya rastlanmamaktadır. Çalışmanın teorik kısmında öncelikli olarak Türkiye'de yapılan otoriteye ilişkin çalışmalardan oluşan literatür incelenmiş, sonra yönetim kavramı kısaca tanımlanmaya çalışılmış, daha sonra ise otorite kavramı benzer kavramlarla ilişkisi, onu oluşturan faktörler, kaynakları, yönetim sürecine ilişkin işlevleri, kullanımının ortaya çıkardığı sorunlar ve bu sorunların çözümüne ilişkin getirilebilecek öneriler açısından değerlendirilmiştir.

\subsection{Literatür İncelemesi}

Yönetim sürecinin harekete geçirici unsuru olarak varsayılan otorite kavramı, tıpk1 sosyal bilimlerdeki diğer kavramlar gibi kolaylıkla ifade edilip açıklanamamaktadır. Bu nedenle her bir kavrama ve bu kavramın ilişkide olduğu diğer kavram ya da olgularla ilişkisine farklı bakış açıları getirilebilmektedir. Yönetim ve otorite iliş̧isine dair yeterli olmasa dahi Türkiye'de bazı çalışmalar yapılmıştır. Yeşertener (1994) Türk Silahlı Kuvvetleri'ne ait bir iş yeri ile bir özel sektör iş yerinde yaptığı otorite ve sorumluluk ilişkine dair çalışmasında kamu sektöründe yasal ve makama dayalı otoritenin, özel sektörde bilgisel otoritenin daha baskın olduğu sonucuna ulaşmıştır. Ayrıca kamuda yetki ve sorumluluğun daha az, özel sektörde ise daha fazla dağıtıldığını tespit etmiştir (Yeşertener, 1994: 100). Tuncer (1999) Türk Silahlı Kuvvetleri'nde liderlik ve otorite ilişkisini incelediği çalışmasında rütbe, cinsiyet, yaş ve eğitim düzeyi fark etmeksizin yöneticilerin otoriter yönetimi tercih ettikleri sonucuna ulaşmıştır (Tuncer, 1999: 159). Aydoğdu (2001) yönetim otoritesinin işyerlerinde ast-üst ilişkilerinin iyileştirilmesi yönünden analizini yaptığı çalışmasında, bu durumun ast ve üst arasındaki güven ve işbirliği ruhu ile otoriteyi kullananın bilgisel, kişisel ve manevi özelliklerine bağlı olduğunu belirtmektedir (Aydoğdu, 2001: 66). Topateş (2014: 382) dinsel otoritenin muhafazakâr işçiler üzerindeki etkilerini incelediği çalışmasında, çalışanların inançlarından kaynaklanan dinsel otoritenin yönetsel otoriteyi desteklediği ya da pekiştirdiği bulgusuna ulaşmıştır (Topateş, 2014: 338). Yıldız (2000) ise çalışmasında otoritenin algı ile yakından ilişkili olduğuna, kültürden kültüre farklılaşabileceğine ve bu nedenle kültürümüze uygun bir otorite davranış ölçeği geliştirilmesi gerektiğine vurgu yapmıştır (Yıldız, 2000: 94). Yiğitceoğlu (2013: 129) ise Türk 
örgüt kültürü ile otorite arasındaki ilişkiyi araştırdığı çalışmasında, Türk örgüt kültürü içerisinde otoritenin yerleşik ve etkin olduğu sonucuna ulaşmıştır.

Yukarıda değinilen çalışmalar genelde otoritenin bir veya birkaç yönetsel unsurla ilişkisine odaklanmıştır. Bu çalışmanın odak konularından biri olan yönetim sürecinde otorite kaynaklı sorunların tespit ve değerlendirmesinin yapılabilmesi için yönetim ve otorite kavramları arasındaki ilişkinin incelenmesi ve anlaşılması gerekmektedir. Bu nedenle önce yönetim daha sonra yönetim bağlamında otorite kavramı açıklanmaya çalışılacaktır.

\subsection{Yönetim}

Yönetim ve otorite ilişkisini tanımlayabilmek için öncelikle, yönetimin dayandığı tarihsel ve toplumsal kökleri açıklamak ve yönetim faaliyetini ortaya çıkaran nedenleri tespit etmek gerekir. Yönetimin ortaya çıkışı için birçok farklı neden sayılabilir fakat temel sebebin insani zaaflar ya da dürtüler olduğunu söylemek yanlış olmaz. İnsanın topluluk halinde yaşama, bir yere ait olma ve başkalarından ilgi görmek gibi önemli psikolojik ve sosyal gereksinimleri vardır (Kağıtçıbaşı, 2006: 259). Diğer yandan ise içerisinde bulunduğu fiziki ve toplumsal yaşam alanının ürettiği tehditlerden korunmak ihtiyacı duyar (Lipson, 1973: 256; Giddens, 2008: 6873). İşte bu iki temel özellik onu toplumsal işbirliğine ve bu işbirliğinin gelişmesiyle bir disipline yöneltir (Fromm, 2006: 94). Bu pratikten elde edilen fayda yönetim faaliyetini, hayatının diğer alanlarında da uygulamasına neden olur. Böylelikle yönetim, toplumsal hayatın ayrılmaz ve vazgeçilmez bir parçası haline gelir.

Yönetim faaliyetinin yer aldığı sosyal süreçlerin içerisindeki insan gruplarının örgütlenmesi incelendiğinde, ilk karşılaşılan yönetenler ve yönetilenler ayrımıdır (Çam, 2005: 317). Adler (1997: 212-216) bu ayrımı itaat eden ve edilen şeklinde yapar. Böyle bir ayrımı tanımlayan ilk kişi Arendt'e (2004: 160) göre Aristo'tur. Bu ayrımın nedeni ise Haldun'a (2005/1: 388) göre, birlikteliğin ve beraber hareketin sağlanabilmesi için çoğunluktaki yönetilenlerin azınlıktaki yönetenlere itaat etmesinin zaruri oluşudur. Aksi takdirde itaat eden ile edilen arasındaki güç farkı azaldıkça birliktelik sağlanamaz. Ancak böylelikle, yönetimin en önemli niteliği olan işbirliği sistemi tesis edilebilir. Canetti'ye (2006: 308) göre bu süreçte, itaat eden bu durumun verdiği psiko-duyumsal koşulları da kabullenmek zorundadır.

Bu koşullardan ilki ve belki de en önemlisi güç eşitsizliğidir. Aron (2007: 37) "eşitlik herkesin güçsüzlüğü sayesinde kurulur" der. Gücün olduğu yerde eşitlikten bahsetmek mümkün değildir (Duverger, 2007: 123). Eşitliğin olmadığ 1 bir yerde ise otoritenin varlığ kaçınılmazdır (Kojave, 2007: 14). Eşitsizliğin bazı temel sebepleri vardır. Bunlar;

a-Teknik zorunluluklar ve teknolojik faktörler (Russell, 2004: 10; Mendel, 2005-b: 80-

b-Sosyal ve ekonomik faktörler (Mendel, 2005-a: 13; 2005-b: 27; Swingewood, 1998: 112-293-294; Duverger, 2007: 125; Arendt, 2004: 136)

c-Psiko-sosyal faktörler (Mendel, 2005-a: 47; 2005-b: 51-52; Russell, 2004: 9)

d-Siyasal faktörler (Kışlalı, 2008: 96; Kapani, 2008: 53-54; Duverger, 2007: 135)

e-Bilgi ve enformasyon faktörü (Foucault, 2005: 161; Giddens, 2008: 895; Kojave, 2007: 27; Krech ve Crutchfield, 2007: 278-279) şeklinde sıralanabilir.

\subsection{Otorite}

Otoritenin varlığına ve tanımına ilişkin felsefi tartışmalar genel olarak çatışmacı ve uyuşumcu olmak üzere iki farklı yaklaşımın ortaya çıkmasına neden olmuştur. Çatışmacı 
yaklaşımda toplum yaşamının baskı üzerine kurulması ve yönetenlerin yönetilenler üzerinde zor kullanması vardır. Uyuşumcu yaklaşımda ise toplum, zaman içinde dengeli ve tutarlı öğelerden oluşan bir yapıdır ve bu yapının öğelerinin uyumu belirli bir biçimde sistem içinde bütünleşmiştir (Çam, 2005: 320). Otorite çatışmacı yaklaşımda çatışmadan, uyuşumcu yaklaşımda toplumdaki uyumdan beslenir.

Otorite üzerine yapılmış önemli araştırmalardan biri de Kojave'nin (2007) çalışmadır. Kojave otoriteyi önce dört arı tipe ayırır. Sonra bu dört arı tip otoritenin düşünce tarihinde hangi felsefi kurama denk düştüğünü belirlemek için, dört arı tipe uygun kuramı saptamaya çalışır (otorite tipi ve kuram ilişkisi Tablo.1. de gösterilmiştir).

Tablo 1: Kojave'de Otoritenin Tipleri, Kaynakları ve Kuramlar

\begin{tabular}{|l|l|l|l|l|}
\hline Kuram / Tip & Baba & Efendi & Reis & Yargıc \\
\hline Skolastik & Neden & & & \\
\hline Hegel & & Risk & & \\
\hline Aristoteles & & & Tasar1-Öngörü & \\
\hline Platon & & & & Adalet \\
\hline
\end{tabular}

Kaynak: (Kojave, 2007)2.

Kojave'nin teorisinde "Baba" nın otoritesinin kaynağı "Neden" dir. Bu otorite, varlığını borçlu olduğu şeye karşı duyulan itaatten beslenir ve kuramını yani felsefi izahını "Skolastik" felsefede bulur. "Efendi" nin otoritesinin kaynağ 1 ise "Risk" tir. $\mathrm{Bu}$ otorite ise efendiyi reddettikten sonra ne olacağı riskini göze alamamaktan beslenir ve izahını "Hegel" in felsefesinde bulur. "Reis" in otoritesinin kaynă̆ 1 "Öngörü" dür. Bu otorite ise yapılacakları veya olacakları önceden bilme ya da onları belirleme gücünden beslenir ve izahını "Aristoteles" in felsefesinde bulur. "Yargıç" 1n otoritesinin kaynağı ise "Adalet" tir. Bu otorite adalet duygusunun insanın derinliklerinden gelen saygınlığından beslenir ve izahını "Platon" un felsefesinde bulur (Kojave, 2007: 21-35). Otoritenin arı tiplerini saf halde gerçek hayatta görebilmek zordur. Aslında gerçek otoritenin somut halleri her zaman karmadır ve dört arı tipin hepsi aralarında bileşir (Kojave, 2007: 36). Böylece farklı arı otorite tiplerinden oluşan karma otorite şekilleri meydana gelir.

Lipson (1973: 251-256) ise otoritenin kaynaklarını Tanrı'nın otoritesi, kuvvetin otoritesi ve ata soyunun otoritesi olmak üzere üçe ayırır. Onun yaklaşımındaki ata soyunun otoritesi, Weber'in geleneksel otoritesini andırır. Weber'de meşru otorite karizmatik, geleneksel ve rasyonel-yasal olarak üç tipte açıklanır (Blau, 1963: 308-309). Geleneksel ile ata soyu otoritesi, üstün olduğuna inanılan insanlara itaat etmeye dayanır. Tanrı'nın otoritesi ile Kojave'deki "baba"nın otoritesinin benzer olduğu söylenebilir. Kuvvetin otoritesi ise seçkin azınlığın çoğunluk üzerindeki tahakkümünü ifade eder. Aslında Weber'deki rasyonel-yasal otoritenin azınlıktaki yasa yapıcılara ya da rasyonel kuralları belirleyenlere bir güç kazandırdığını düşünürsek, kuvvetin otoritesi ile karş1laştırmak daha kolay olur. Lipson (1973: 258) otoritenin seçkinlerde olmasında örgütlülügün önemine vurgu yapar. Örgütlülük çoğunluğa karşı azınlığa üstünlük sağlar. Bütün sosyo-politik ilişkiler üretilen bu eşitsiz ilişkiyi kullanır ve iktidarlarını sağlamlaştıracak araçları geliştirir (Mendel, 2005-b: 57).

\footnotetext{
${ }^{2} \mathrm{Bu}$ tablo eserin içeriğinden esinlenerek çalışmada türetilmiştir.
} 
$\mathrm{Bu}$ nedenle modern dönemlerde yaşanan teknolojik devrimler, kültürel etkileşimler, toplumsal ve iktisadi altüst oluşlar dahi otoritenin etkisini azaltamamıştır (Mendel, 2005-a: 243). Çünkü otorite başka biçimler altında, manipüle edilmiş, çehre değiştirmiş bir halde sürmektedir (Mendel, 2005-a: 99). İnsanlar otoriteyi temsil eden kişilerin karakterlerinden tiksinti ile bahsetmesine ve onların maksatlarında kötülükler sezmesine rağmen, aslında o kimselerin üstünde bulunanların önünde eğilmeye devam etmektedir (Jouvenel, 1997: 43-44). Mendel (2005-b: 60) bunun en önemli sebeplerinden birinin terk edilme duygusu olduğunu öne sürer. Lipson (1973: 248) ise nedeni, insanın otoriteyle çatışma yaşamak istememesi ve uyumlu görünmek istemesinde görür. İnsanın otoriteye itaatini, menfaat ve çıkarları korumak endişesine bağlayanlar da vardır (Lukes, 2002: 647; Dönmezer, 1999; 271). Fakat otoritenin psikolojik ve toplumsal nedenlerinin daha ağırlıkta olduğu söylenebilir (Mendel, 2005-b: 49; Kojave, 2007: $57)$.

Çünkü Mendel'e göre (2005-b: 23) otorite, fiziksel zorlamaya başvurmadan boyun eğene karşı belli bir davranışı kabul ettirecek bir gücü elde tutmaktır. Otoritenin psişik temeli, buyruk vermeyle boyun eğme arasındaki ilişkinin içine yerleşir ve bu da otoritenin toplumsal bir olay gibi sayılmasına izin verir. Otorite boyun eğen üzerinde bir değişim etkisi üretir (Kojave, 2007: 13). Burada önemli olan değişimin konusu değil değişimi kimin istediğidir. Konu bir bakıma ikincil bir öneme sahiptir (Lukes, 2002: 634). Arendt (2004: 164) eğitim sisteminin aslında siyasal egemenlik niyetini gizlemeye yaradığını ve aslında tahakküm kurmak isterken eğitirmiş gibi yapılmasına hizmet ettiğini öne sürer. Bu nedenle söylenebilir ki otorite, toplumsal hayatın kendine içkin bir durumdur ve bütün sosyal kurumların içinde gömülü bir şekilde az ya da çok bulunur.

Geçmişte kutsallıktan beslenen otoritenin, günümüzde rasyonelleşip demokratikleşmiş gibi görünmesi çelişkili bir durumdur (Mendel, 2005-a: 13; Mendel, 2005-b: 58). Çünkü otorite Kojave'ye (2007: 15) göre, uzlaşma yapılmaksızın eyleme geçme olasılığını ifade eder. Bu nedenle demokratik bir otoriteden bahsetmek zordur. Ancak otoritenin, meşruiyet kazandırılmış haklı bir güç ${ }^{3}$ olduğunu söylemek gerekir (Hodgkinson, 2008: 85-87). Otoritenin toplum içinde görünür ya da görünmez bir hiyerarşi meydana getirdiği (Arendt, 2004: 136) ve gücünü her zaman yukarıdan aşağıya doğru uyguladığı bir gerçektir (Mendel, 2005-b: 28). İktidar kavramı da hiyerarşik olarak güç kullanmasından dolayı otorite ile genelde birbirine karıştırılır fakat iktidarın "güç kullanma yetkisine sahip meşru otorite" olarak yapılan tanımı daha çok kabul görür (Jovenel, 1997: 49-50; Lukes, 2002: 631; Duverger, 2007: 125; Kojave, 2007: 70).

Otoriteyi benzer kavramlardan ayıran en önemli özelliklerinden biri etkisinin göreli olarak uzun sürmesidir. Bunun sebebini ise onu besleyen kaynaklarda aramak gerekir. Kojave (2007: 42) otoritenin her gerçek kaynağının zorunlu olarak kendiliğinden olduğunu ve koşullu kaynakların bunların sadece aktarımı durumunda olduklarını belirtir. Arendt ise (2004: 134-135) otoritenin kaynağını daima yönetimin kendi gücünü aşan bir dış güçten aldığını öne sürer ve yönetimlerin bu gücün kontrolü altında olduğunu ifade eder. Otoritenin kaynaklarına ilişkin iki genel yaklaşım vardır. Bunlardan birincisi "formel otorite yaklaşımı" diğeri ise "otoritenin kabulü" yaklaşımıdır. Formel otorite yaklaşımı biçimseldir ve otoritenin görünümünü esas alır (Yeşertener, 1994: 11). Burada otoriteye hiyerarşik düzeydeki statüsünden dolayı uyma söz konusudur. Otoritenin kabulü yaklaşımı ise, önermelerin doğruluğu ve kaynakları otorite olarak

\footnotetext{
${ }^{3}$ Kojave, güç ile otoritenin birbirlerini dışladıklarını ve zıt olduklarını iddia ederken (bkz: Kojave, 2007: 16) Mendel, bu görüşe katılmaz ve otoritenin güç kullanmayı da kapsadığını öne sürer (bkz: Mendel, 2005-a: 32). Arendt ise otoritenin dışarıdan zorlayıcı araçlar kullanılmasını men ettiğini; zorun geçerli olduğu yerde, otoritenin de iflas etmiş olacağını düşünür. Otoritenin ikna ile de ilgisi olmadığını, ikna sürecinde varolan eşitlikçi yapının, her zaman hiyerarşik olagelmiş otoriter yapıyla taban tabana zıt olduğunu öne sürer. Bu nedenle otorite tanımının hem argümana dayanan iknayla hem de güce dayanan zorlamayla karşıtlık içinde olması gerektiğini vurgular (bkz: Arendt, 2004: 129)
} 
görüldügü için kabul edilir anlayışına dayanır ${ }^{4}$ (Lukes, 2002: 637; Duverger, 2007: 136; Kojave, 2007: 16-17). Burada otoriteye itaat daha içsel ve kendiliğindendir.

Otoritenin meşru bir güç olduğundan ve diğerlerini etkileme kapasitesine sahip olduğundan bahsedilmişti. Bu nedenle denilebilir ki, otoritenin iki temel kaynağı güç ve meşruiyettir. Bu güçler aynı nitelikte olmayıp farklı türlerde sınıflandırılabilir. Bunlar;

a-Zorlayıcı güç (Şahin, 1999: 9; Şimşek, 1998: 168)

b-Ödüllendirme gücü (Şahin, 1999: 9; Koçel,1999: 411)

c-Yasal güç (Şimşek, 1998: 168; Bayrak, 2001: 26)

d-Uzmanlık gücü (Bayrak, 2001: 26; Şahin, 1999: 10; Çınar, 2006: 235) siralanabilir.

e-Karizmatik gü̧̈ (Koçel, 1999: 411-412; Bayrak, 2001: 27; Şimşek, 1998: 169) şeklinde

Otoritenin meşruiyeti ise; ideolojilerden (Y1ld1z, 2000: 23; Dönmezer, 1999: 358), toplumsal yapının özelliklerinden (Hodgkinson, 2008: 95), yöneticinin kişisel niteliklerinden (Dönmezer, 1999: 271; Yıldız, 2000: 15) ya da yönetilenlerin rızasının kazanılmasından (Dönmezer, 1999: 270; Küçükalp, 2008: 1; Çınar, 2006: 237) elde edilebilir.

Otoritenin elde edilmesiyle yönetim ya da yöneticiler bazı yönetsel işlevleri de kazanmış olur. Bunlar; yönetme yetkisi (Yeşertener, 1994: 36; Eren, 2003: 253), disiplini sağlama ve iş yaptırma (Lukes, 2002: 642; Şahin, 1999: 17; Küçükalp, 2008: 1), işyerinde manevi ortam sağlama (Dönmezer, 1999: 269; Sennett, 2005: 207; Eren, 2008: 385), sosyal statü ve saygl oluşturma (Duverger, 2007: 136-137; Yıldız, 2000: 35), itaati temin etme (Koçel,1999: 409; Mendel, 2005-a: 11) olarak suralanabilir. $\mathrm{Bu}$ işlevler yöneticinin yönetim faaliyetini sürdürmesinde önemli rol oynar. Yönetici otoriteyi direkt (doğrudan) otorite, yardımc1 otorite, fonksiyonel (işlevsel) otorite, resmi ve gayri resmi otorite (Yeşertener,1994: 15-17) şeklinde kullanabilir.

Otorite yönetim alanında; güvene (Şahin, 1999: 14), benimsemeye (Duverger, 2007: 130; Şahin, 1999: 14-15), yaptırımlara (Aydoğdu, 2001: 18; Şahin, 1999: 15), töreye uygunluğa (Şahin, 1999: 15; Aydoğdu, 2001: 20) dayanabilir. Yöneticiler sevk ve idare eylemini gerçekleştirirken; bilgisel otoriteyi ${ }^{5}$ (Şahin, 1999: 15; Çınar, 2006: 235), mevkiye dayanan otoriteyi (Aydoğdu, 2001: 23-24; Şahin, 1999: 15-16), kişisel otoriteyi (Şahin, 1999: 16; Berberoğlu, 1985: 138), manevi otoriteyi (Hodgkinson, 2008: 93; Şahin, 1999: 16) kullanabilir. Bunu otoriteyi dağıtarak (Kojave, 2007: 52; Başaran, 2004: 113) ya da bölerek (Kojave, 2007: 72) yapabilir. Fakat otoritenin yönetim faaliyetlerinde kullanımı sırasında bazı sorunlar ortaya çıkabilir ve yönetim bu sorunları çözmek için bazı tedbirler alabilir veya yöntemlere başvurabilir.

\footnotetext{
${ }^{4}$ Mendel, otoritenin insanda nasıl içsel bir kabule dönüştüğü süreci şöyle anlatır: "Terk edilme bunaltısının ve suçluluk duygusunun artırılması ve sürekli kılınması, toplumların içinde saptanabildiği gibi, ayrıca otoritenin de kökenidirler. Çocuk kendi ruhsal-duygusal gelişimini izleyeceği yerde, yanıltıcı tehlikelere terk edilmiş olmamak için, boyun eğmeye alışır. Otoriteye boyun eğen bilinçsiz bir refleks, uzun süreç içinde işte böyle yapılanır. Böyle bir boyun eğme davranışı, kendi uzak kökeniyle bağlantı kurma yeteneğinde olmayan çocuğa ve yetişkine sonunda tümüyle doğal gelir (bkz: Mendel, 2005-b: 64)

${ }^{5}$ Hodgkinson'a göre, bilgi otoritesi ile mevki otoritesi yani hiyerarşi arasında zıtlıklar vardır ve bu ikisi birbiri ile çatışabilir. Bilgi otoritesi komuta zincirine dikeydir ve potansiyel olarak özerktir. Hiyerarşik otorite ile rekabet halindedir ve çoğu zaman yönetimin hiyerarşik otoritesinden çok daha doğrudan bir örgütsel misyona sahiptir (bkz: Hodgkinson, 2008: 91)
} 


\subsubsection{Otorite Kullanımının Ortaya Çıkardığı Yönetim Sorunları}

Otorite yönetim faaliyetlerinde ister yanlış kullanımından isterse amacı dışında kullanımından olsun bazı sorunlara sebep olur. Bu sorunları tartışmaya geçmeden önce otoriteye ilişkin bazı eleştirilere değinmek fayda sağlar. Arendt (2004: 127) otoritenin kendini insanlara apaçık göstermediğini ve bu yüzden varlığının kolayca hissedilemeyeceğini söyler. Onun için otorite muğlâktır ve tasavvuru güçtür ${ }^{6}$. Bu yüzden otoriteyi, insanların var ettiği bir güç ve zayıflık olarak tasavvur etmekte de zorluk çekilmektedir. Sennett (2005: 208) de bu özelliğinden dolayı, kamusal alanda insanların otoriteye başkaldırıp itiraz edebilmelerine rağmen özel yaşamda kendi tasavvurları olan ve kendilerinin var ettikleri otoriteden soyutlanamayacaklarını ifade eder. Lukes (2002: 657-658) Pareto'dan hareketle otoriteyi, mantıki olmayan eylemler ile bu eylemlerin kaynaklandığı duyguları mantıkileştirmenin aracı olarak tanımlar. Ona göre otorite; Protestanın, Katoliğin, Rousseau'nun bir pasajıyla kendinden geçen hümanistin, Marx ve Engels'in adı üzerine yemin eden sosyalistin, sınırlı ya da genel oy hakkı daha da kötüsü parlementolar ve kanun koyucular önünde saygıyla başını eğip muhakemesini ve iradesini teslim eden sofu demokratın hoşuna gider. Otorite, günümüz toplumlarında sadece eğitimli olmayanlar için ya da din ve ahlak gibi dokunaklı konularda değil, bilimsel çalışmalarda ve akademilerde, sanat ve düşünce alanlarında bile geçerlidir. Bu çevrelerin kamusal alanlarda var saydıkları otoritelere karşı sergiledikleri itirazcı tutum, kendi içsel dünyalarında var ettikleri otoritelere karş1 aynı tutarl11ıkta sürdürülememektedir.

Otorite sosyal ilişkilere içkinliği, gizliliği ve kolay fark edilememesi ve toplumsal yapının her alanına nüfuz etme özelliğinden dolayı oldukça etkindir. Yönetim alanında bu etkinliği; güç taşkınlığı (Eroğlu, 2009; Sanford, 2006: 71-74), çıkar sağlama, otoriteyi kendinde toplama, sorumluluktan kurtulmak için otoriteyi dağıtma (Dereli, 1985: 177-181) şeklinde art niyetli olarak kötüye kullanılabilir. Örgütlerdeki yönetim ve organizasyon faaliyetlerinin fiilen gerçekleşmesi sırasında ne yazık ki başlangıçta kabul edilen ve rıza gösterilen "formel hukuki kurallara" bizzat uygulama sırasında aynı duyarlılık ve ideal ölçülerde uyulmadığı görülmektedir (Eroğlu ve İ̀miş, 2004: 105). Bu tutarsızlığın ortaya çıkmasında otoritenin de etkisi söz konusudur. Çünkü Kojave'ye (2007: 61) göre otorite sonsuzdur. Otoriteyi elinde tutan yöneticiler de muhtemelen bu düşünceye kapılarak, onun kendi şahıslarına münhasır olduğu yanılgısına düşer ve kendileri var oldukça otoritenin etkisinin de her daim var olacağını sanmaya başlar. Zamanla otoritelerinin sarsıldığını gördükçe ya da böyle bir sanıya kapıldıklarında, otoritelerinin yeninden tesisi ya da otoritelerini sürdürebilmeleri için farklı yollara başvurur. Bunlardan en sik başvurulanı ise zorla ya da dayatma yoluyla otoritenin sağlanması ya da sürdürülmesidir. $\mathrm{Bu}$ güç taşkınlığı olarak ifade edilen durumdur ve Arendt'in (2004: 193) otoritenin kaynağının yöneteni aşan bir güce dayandığı fikrinin kaybolmasının bazı olumsuz sonuçlar doğuracağını söylemesinin nedeni bu olsa gerektir.

Uzlaşım yoluyla otoritenin gönüllü kabulü yolunu (Lukes, 2002: 639) değil de dayatma yolunu seçen yöneticiler eğer bir de yönetme ehliyet ve liyakatine sahip değillerse sorunların derinleşmesi kaçınılmazdır. Yöneticilerin başarılı ve etkili bir yönetimin gerektirdiği hukuki otorite ve uzmanlık gücü ile yeterli ölçüde donanmadıkları durumlarda, çalışanlar üzerinde ilk tesis ettikleri iş yaptırma ya da gördürme gücü, çoğunlukla "korku" yaratma ve yayma davranış1

\footnotetext{
${ }^{6}$ Sennett'e göre otorite, somut bir şey değil, hayal gücünün ürünüdür. Başkalarının gücünde, somut gibi görünen bir sağlamlık ve güvenlik arayışıdır. Bu arayışın sona ereceğine inanmak yanılsama ve yanılgıdır (bkz: Sennett, 2005: 209). Arendt ise otoritenin, artık canlılar arasında bulunmayan kurucuların otoritesinden kaynaklandığını ve köklerinin geçmişte olduğunu vurgular (bkz: Arendt, 2004: 167). Jouvenel de bu görüşe katılır ve otoritenin gücünün çok eski çağlardan gelen hislerimizde bulunduğunu belirtir (bkz: Jouvenel, 1997: 46). Mendel ise otoriteyi gizeme ve az bilinirliliğe dayandırarak onun muğlaklığına ve tasavvurundaki güçlüğe dikkat çeker. Fakat diğer yandan bu özelliğinin merak duygusunu tetikleyerek etkisini sürdürmesini sağladığını öne sürer (bkz: Mendel, 2005-b: 35)
} 
olmaktadır (Eroğlu ve İrmiş, 2004: 104). Bu yöntem otoritenin yönetilenler açısından kötüye kullanımında en sık rastlanılanıdır (Başaran, 2004: 113) ve günümüzde yönetimlerin en fazla başvurdukları yönetme tavrı olarak nitelenmektedir (Eroğlu ve İrmiş, 2004: 106). Bask1 ve korkutmanın yaygınlaşması ise çalışanların sorumluluk alarak kendi başlarına hareket edemeyecekleri yönünde kötümser bir inancın oluşmasına neden olmaktadır (Jondt, 1998: 167168). Sonuçta çalışanda inisiyatif alma alışkanlığ oluşmamakta ve sorumluluk bilincinin gelişmesi engellenmektedir.

Korku ya da dayatma yolunu bir yöntem haline getiren yöneticilerde ise zamanla otoriteryen $^{7}$ bir kişilik meydana gelmektedir. Otoriteryen yönetici hiçbir zaman yönetilenlerle aynı düzeyde durmaz ve bu yüzden ona daima aşağıdan yukarıya doğru bakılır (Mendel, 2005-b: 46). Bu durum otoriteye sahip olan kişilerde psikolojik bir üstünlük algısı oluşturur. Karşı tarafta da otoritenin üstünlügüne olan inancı pekiştirir. Otoritenin yanlış kullanımındaki en önemli sorunlardan biri onun sonsuz ve sınırsız kullanılabileceği düşüncesi iken diğer bir önemli sorun ise onun her meseleye ilişkin genel geçer kullanılabileceği kanaatidir. Bu anlayışta keyfiyet, şiddet, ölçüsüzlük, sınırsızlık, irrasyonalite kendini gösterir (Mendel, 2005-a: 88). Tek geçerli yönetim biçimi ya da modelinin otoriter yönetim olduğu yönünde bir kanaat oluşur ve bu zamanla içselleşir.

Otoritenin sınırsız ve genel geçer kullanımının yönetilenlerde meydana getirdiği tahribat ise işin bir başka boyutudur. Le Bon (2005: 38-51) kitlelerin güce karşı saygı beslediğini ve onun etkisi altında kalmaya uygun olduğunu belirtir. Otorite kitleleri etkilerken onların hayalleri üzerinden bunu gerçekleştirir. Dahl (2002: 80) ise otorite ile etkiyi adeta özdeşleştirir. Canetti'ye göre (2006: 97) kitleler iki türlüdür. Dışa dönük kitle kendisinin dışındaki bir hedefe yönelik hareket ederken, içe dönük kitle ise tek merkezlidir. Temel hedefi bir şeye ulaşmak değil, onu elde tutmaktır (Canetti, 2006: 118-119). Otoriter yönetim örgütleri de içe dönük kitle özelliği taşır. Onlar gibi tek merkezli ve bir hedefe ulaşmaktan çok var olanı korumayı amaçlar. Yönetilenlere vaatlerde bulunur fakat tek amacı gücü elinde tutmak olduğundan, yönetilenler açısından kaçınılmaz son hayal kırıklığına uğramaktır.

Günümüzde belki de asıl sorun insanların otoriteyle ilişkilerinin gerçek yüzüdür. İnsanlar korku ya da dayatma gibi güç taşkınlıklarından hoşlanmadıklarını ifade etseler bile otorite ile ilişkilerini belirli düzeyde tutma konusunda istekleri tartışmalıdır. Le Bon (2005: 84) yönetilenlerin bağlllığa önem verdiklerini ve bu durumun içgüdüsel olarak gerçekleştiğini iddia eder. Canetti de (2006: 307-311) yönetilenlerin otoriteden emir almalarının insanın tabiatına uygun olduğu görüşündedir. Emir alma insanda içsel bir rahatsızlık meydana getirse de bundan kaçamaz. Fakat otoritenin açı olarak uygulandığ geçmiş yönetim biçimlerinde, emirleri kimin verdiği, yasakları kimin koyduğu bilinirdi. İstenenler ya da yasaklananlar, akla yatkın ya da aykırı, sert ya da yumuşak olabilirdi. Bunlara baş kaldırılabilir veya boyun eğilebilir ama bir otoritenin var olduğu, kim olduğu, ne istediği, başkaldırmanın ya da boyun eğmenin sonucunda ne olacağ 1 bilinirdi. Günümüz yönetim biçimlerinde ise otoritenin niteliği değişti. Günümüz otoritesi daha çok bilinmeyen, görünmeyen ve dokunulmayan bir özellik kazandı. İnsanlardan

\footnotetext{
${ }^{7}$ Kağıtçıbaşı'na göre otoriteryen kişilik kuramı, ön yargılı 1rk ayrımı tutumunu ele alarak bunu kişiliğin derinine inen bir eğilim olarak kabul etmiştir. Bu kurama göre, erken çocukluk çağında sevilmeme, hor görülme gibi ego (benlik) yıpratıcı yaşantılar, kişide kendini hor görme eğilimi geliştirir. Ancak, kişinin kendini değersiz bir kimse olduğunu kabullenmesi çok kaygı verici bir durum olduğundan, kişi ego-savunma mekanizmaları kullanarak kendisinin değersiz olduğu inancını bilinçaltına bastırır. Ayrıca yansıtma yoluyla, hor görmeyi kendisinden başkasına yöneltir. Yani kendini değil, başkalarını değersiz olarak görmeye başlar, onlara karşı nefret ve saldırganlık duyguları geliştirir. Bu durumda, kişinin önyargılı ayırımcı tutumu, aslında kendinin de farkında olmadığı bir gereksinmeyi karşılamaktadır. Bu gereksinme, yıpranmış olan egosunu tamir etmek, yükseltmektir. Kişiliğin derininde yatan bu tür gereksinme kolay kolay ortadan kalkamayacağı için, böyle bir gereksinmeyi tatmin eden bir tutum da kolay değişmeyecek demektir (bkz: Kağıtçıbaşı, 2006: 171)
} 
otoriteye dair açıkça bir şey istenmediği halde, otoriteye eski toplumlardan daha çok itaat edilir oldu. Kar, ekonomik zorunluluklar, pazar, sağduyu, kamuoyu, insanın yaptıkları, düşündükleri, duyguları günümüz otoritesinin görünen yeni halleridir. Fakat bunlar farklı söylemler halinde karşımıza çıkar. İş hayatında ve yönetim sürecinde ise daha başka bir biçime bürünür. Yönetici belki emir vermez, öneride bulunur fakat altında gizli bir tehdit saklar. Buyurmaz ama dil dökerek kandırır ya da çeşitli manevralar yaparak otoriteye boyun eğdirir. Bu manevralardan veya kandırma yöntemlerinden biri de özdeşleşme talebidir. Kabul edilebilir olmak, gerçekte başka kimseden farklı olmamak demektir yani diğerleriyle aynı olmaktır. Bu tam da bilinmeyen otoritenin işlemesini sağlayan topluma uyma yani herkesin yaptığını yapmam gerekir mantığının psikolojik şartlanma halidir. Bu ödünlü hal, bir tutsaklık, bir bensizlik ve ruhsal bir çöküntü yaşamıdır (Fromm, 2006: 143-152).

Otoritenin kullanımından kaynaklı yönetim sorunları yöneten, yönetilen ve yönetim faaliyeti bakımından kısaca açıklanmaya çalışıldı. Bu sorunlara yönetim stratejileri temelinde bazı çözüm önerileri getirilebilir. Fakat genel kabul edilmiş çözüm yollarının dışında farklı alternatifleri de tartışmak gerekir.

\subsubsection{Otorite Kaynaklı Sorunlara Bazı Çözüm Önerileri}

İnsanlar otoriteden öncelikle kendi kabul alanlarıyla çelişmeyen ya da o alanın sınırlarını aşmayan taleplerde bulunmasını ister. Somut bir durumda, çalışanın emri yerine getirmesini sağlayan sebep bunun uygunluğuna kani olması, vazife duygusu, korku, alışkanlık ya da kendisi için yarar elde etme arzusu olabilir (Lukes, 2002: 635). Bu nedenlerin hangisinin daha etkin olduğu otorite ile yönetilen arasındaki ilişkiye göre değişir. Bazı durumlarda otorite kayıtsız şartsız kabul edilirken (Mendel, 2005-a: 244), bazı durumlarda otorite kısmen kabul edilebilir (Küçükalp, 2008: 2; Mendel, 2005-b: 9), bazen ise otorite tamamen reddedilebilir (Mendel, 2005-b: 11; Eroğlu ve İrmiş, 2004: 107). Otoritenin reddi genelde yöneticilerin gerekli uzmanlık ve niteliklere sahip olmadıkları algısı yaygınlaştığında görülür. Eğer örgütsel amaçlara ulaşılması uzmanlığa bağımlı araçların kullanılmasına bağlı ise, örgüt ikilikçi bir otorite yapısına meyledecektir (Hodgkinson, 2008: 92-93). Böylelikle hiyerarşik yapıda aksamalar ve yönetimde zafiyetler meydana gelecektir. Yöneticiler eğer hiyerarşideki mevkilerine meşruiyet kazandırmak istiyorlarsa ya hiyerarşi ve uzmanlığın çatışan otoritelerini örgütsel birlik içerisinde uzlaştırmak ya da yönetici mevkilerine alanının uzmanı, eğitimli, deneyimli, ehliyet ve liyakat sahibi kişileri getirmek zorundadır.

$\mathrm{Bu}$ anlamda yöneticilere yapısal çözüm olarak; yetki devri (Yeşertener, 1994: 51; Şimşek, 1998: 144), yetki ve sorumluluk denkliğinin sağlanması (Yeşertener, 1994: 51; Şimşek, 1998: 144), yetkinin işlevsel dağıtımı (Şimşek, 1998: 150), yetkinin adil dağıtımı (Eroğlu, 2009) yolları önerilebilir. $\mathrm{Bu}$ süreçte yöneticiler geleneksel olarak; ekonomik düzenlemeler, iş ortamının iyileştirilmesi, personelin motivasyonu, işgören ve yönetilenlerin güçlendirilmesi (Şimşek, 1998: 194-195; Koçel, 2005: 416) gibi tedbirlere başvurabilir. Fakat bu uygulama ve tedbirler otorite kaynaklı yönetim sorunlarının tamamını çözmede başarılı olamayabilir. Bunun için insanın ahlak ve vicdan gibi değer özellikli ve eylemlerinde tutarlılık sağlayabilecek yönlerine ihtiyaç duyulabilir.

\subsubsection{Alternatif Bir Çözüm Önerisi Olarak Ahlak Kavramının Tartışılması}

Otoriter yönetimlere, örgütün ya da işletmenin amaçlarına erişme bakımından tamamıyla başarısız demek mümkün değildir. Fakat yönetim uygulamalarını ve biçimlerini değerlendirirken sadece örgütün ya da işletmenin somut hedeflerine ne derece ulaşıldığı ve ne gibi şeyler elde edildiğine bakmaktansa, hedeflere gidilen süreçte yönetime katılan çalışan ya da bireylerin 
ekonomik, sosyal ve psikolojik menfaatlerini, kazanımlarını ya da zararlarını da dikkate almak gerekir. Çünkü eğer bir yönetim örgüt, işletme, iktidar gibi soyut kavramların amaçlarını dikkate alıp onları meydana getiren bireylerin ekonomik ve sosyal çıkarlarını, duygu ve düşüncelerini, psikolojik tatmin ve beklentilerini hiçe sayıyor ve bunların aksine hareket edebilmeyi göze alıyorsa, bu yönetimin anlayışında eksiklik, hata ve yanlışlıkların var olduğu iddia edilebilir ${ }^{8}$. Bu nedenle yönetimlerin ve yöneticilerin, yönetmiş oldukları insanların duygu ve düşüncelerini, arzu ve beklentilerini de dikkate alan bir anlayışı benimsemeleri gerekmektedir. Çünkü insan sahip olduğu psikolojik ve bilişsel yapısıyla, içinde bulunduğu toplum ya da örgütün amaçlarını aşan ya da onlardan farklılaşan beklentiler içerisinde olabilmektedir.

$\mathrm{Bu}$ nedenle yönetim ve organizasyon süreçlerinin gerçekleştirilmesi sırasında ortaya çıkan yönetme iradesindeki boşluğun doldurulmasında bir "değerler sistemine" ihtiyaç duyulduğu söylenebilir. Böyle bir değerler sisteminin varlığ 1 , meşru ve rızaya dayalı hukuk kurallarının boş bıraktığı alanların doldurulmasını sağlamanın yanında, çalışanları bulundukları iş ortamındaki faaliyetlere ve karar süreçlerine katılmaları konusunda da isteklendirecektir. Ayrıca, bir iş örgütündeki hukuki ve biçimsel kurallara ne derece uyulacağının en önemli belirleyicisi, ahlaki değerler hakkındaki tutarlı ve içten tutumlardır. Ahlak, hem hukuki kurallara uyulması konusundaki duyarlılığı yükseltmekte, hem de herhangi bir belirsizlik karşısında çalışanlara nasıl davranılması gerektiği konusunda, sonunda pişmanlık ve suçluluk duyulmayacak bir seçimin yapılmasına katkıda bulunmaktadır (Eroğlu ve İrmiş, 2004: 106). İster özel sektör işletmelerinde isterse kamusal alanda olsun yönetimlerin bu katkıya ihtiyacı görmezden gelinemez. Çünkü modern döneme rengini veren pozitivist bilim geleneğinin, ahlak sorununu geri atmasına (Kılıç, 1998: 39) ve insanın hayatını düzenleyen kişisel olmayan yasaların bireye tercih edilmesine (Touraine, 2007: 283) rağmen sorunlar hala tam olarak çözülebildiği iddia edilememektedir.

Bireyi ikinci plana atan anlayış, direkt olarak ifade edilmese de akıl-insan çatışmasının üstü örtülü bir şekilde devam ettiğinin bir göstergesidir. Zihinlerdeki bu karşıtların çatışması ve otorite, insanlığın gelişimi boyunca birçok değişikliğe uğradı. Günümüz de ise bilinçdışının gücü olarak adlandırabileceğimiz iç otorite ve toplumsal baskı olarak adlandırılan dış otorite göreceli bir durum aldı. Göreceli bir durum alan otorite uygulaması, manipüle edilip üzeri başka kavram ya da görüntülerle örtüldügü için rahatlıkla seçilip somut bir şekilde ortaya konamadı. İçsel olarak şiddetini hissettiren bu tahripkâr tavra ancak yine içsel ya da ruhsal bir olguyla baskın çıkılabilir (Mendel, 2005-b: 10). Klasik anlamda değerlerin aşındırıldığı ve işlevsiz bırakıldığı postmodern zamanlarda "korku" son derece inceltilmiş ve hatta estetize edilmiş birçok "korkutma" ve "yıldırma" yöntemleri sayesinde, yönetim ve organizasyon faaliyetlerinde önemli bir yönetsel güç haline gelmiştir. Yönetim ve organizasyon faaliyetlerinin başarılı, etkili ve verimli bir şekilde gerçekleşmesi için, birçok otorite tipinin yanında hala otorite boşluğu kaldığı zamanlardaki durumları yönetmek için bir "ahlaki otoritenin" varlığı kaçınılmazdır (Eroğlu ve İrmiş, 2004: 107). Kant'ın da dediği gibi "insanın ahlaklı eylemlerinin kaynağı olan aklının, iyiye doğru bir ilerleme, bir gelişme olduğuna inanması ve bunu umması gereklidir. Böyle bir umut olmaksızın insanın, insanlığın mutluluğu için kalbini çarptıran, onu canlandıran bir atılım yapmasına olanak kalmaz" (akt. Heimsoeth, 2007: 181-182). Bröckling de (2008: 162) yönetim faaliyetinde ahlaki güçlerin harekete geçirilmesini, bedenin disipline edilerek denetlenmesinden daha önemli görür. Ona göre çalışanlar dış baskılardan ötürü değil de, kendi içlerinde oluşan kanaat ve arzuyla itaat etmelidir.

\footnotetext{
${ }^{8}$ Mendel, "verimlilik" ilkesi uğruna temel insani değerlerin nasıl çiğnendiğini (bkz: Mendel, 2005-b, 84) ve insanın yaratıcılık özelliğinin yok edilerek bireyin nasıl ortadan kaldırıldığını çarpıcı bir üslupla anlatır (bkz: Mendel, 2005-b, 62)
} 
İstek ve içtenlikle gerçekleştirilen faaliyetler, yönetim açısından sorunların azaltılmasında büyük katkı sağlar. Bu amaçla yönetim anlayışının fayda ve zararın yanında, iyi ve kötü kavramlarına da yer vermesi önemlidir. Toplum ve örgütlerde neyin iyi neyin kötü olduğu hakkında oluşturulacak ortak bir anlayış, karmaşa yerine düzen ve huzurun tesisini sağlayabilir (Kılıç, 1998: 40). Bu anlayış sayesinde oluşan ahlaki kurallar, toplumsal ve örgütsel üyelerin istenilen belirli tavır ve davranışları sergilemesine yardımcı olur. Üyeler tarafindan hissedilen bu kurallara uyma mecburiyeti, toplumsal ve örgütsel açıdan "sosyal kontrol mekanizmalarını" meydana getirir. Fakat insan, ömrü boyunca hep başkalarının bekleyiş veya tepkilerine göre davranışlarda bulunmaz, gerekli zihni olgunluğa eriştikçe bu davranış kaidelerini bir sistem halinde benimser ve artık her davranışı bu sisteme göre değerlendirir. İște bu noktada vicdan dediğimiz "iç kontrol mekanizması" teşekkül etmiş olur (Güngör, 2005: 58).Yönetim anlayışıyla ilgili olarak ortaya çıkan olumsuzlukları önlemenin diğer bir yolu da insani vicdan duygusunun geliştirilmesidir. Otoritenin ya da yönetenin kontrol edemediği ve yönetim sürecinin olumsuz anlamda etkilendiği durumların ortaya çıkmaması için, yönetilenlerde bir vicdan duygusunun oluşması ve içselleşerek yerleşmesi zaruridir. Aynı zamanda adaletli bir yönetimin sergilenebilmesi için yönetenlerde de bu duygunun var olmas1 gerekmektedir. Çünkü vicdan bir kaideler sistemidir ve bu sistem insanın kendi davranışları veya başkalarının davranışları hakkında "doğru" veya "yanlış" şeklinde yargıda bulunmasını sağlar. Doğru olarak değerlendirilen davranışlar, insanın kendi benliğine karşı iyi ve olumlu duygular beslemesine yol açar, "yanlış" veya "kötü" sayılan davranışlar ise suçluluk duygusu yaratır (Güngör, 2005: 57). Bu suçluluk duygusu yöneticilerin, çalışanlarına haksız, adaletsiz davranmalarına engel olmakla beraber, kaynakları ve imkânları kendi çıkar ve menfaatleri doğrultusunda kullanmalarını da engeller. Diğer yandan da çalışanların yönetimin kontrol edemediğini düşündüğü alanlarda iş yavaşlatma, işi sabote etme, kaynakları israf etme gibi örgütsel faaliyetin etkinliğini düşüren bir tavra yönelmelerine mani olur. Böylelikle hem yönetim en az sorunla gerçekleştirilir hem de yöneticilerin ve yönetilenlerin memnuniyet duygusu tatmin edilerek, tüm kesimlerin rıza gösterdiği bir yönetim anlayışı sergilenmiş olur.

\section{YÖNTEM ve ARAȘTIRMA}

\subsection{Araştırmanın Amacı}

Araştırma, kamu iş örgütlerinde çalışan personelin otoriteye ilişkin tutum ve düşüncelerini tespit etmeye çalışmaktadır. Bunun için aşağıdaki araştırma sorularının cevaplarını bulmayı amaçlamaktadır.

Araştırma sorusu-1: Kamu çalışanları otoriteyi ne olarak görmekte ya da nasıl algilamaktadır?

Araştırma sorusu-2: Kamu çalışanları otoritenin işlevleri hakkında ne düşünmektedir?

Araştırma sorusu-3: Kamu çalışanları yöneticilerin otoriteyi kullanım biçimlerine ilişkin ne düşünmektedir?

Araştırma sorusu-4: Kamu çalışanları otoritenin ne gibi sorunlar meydana getirdiğini düşünmektedir?

Araştırma sorusu-5: Kamu çalışanları otorite kaynaklı sorunlara hangi yöntemlerin çözüm getirebileceğini düşünmektedir?

Araştırma sorusu-6: Kamu çalışanları otorite kaynaklı sorunların çözümünde "ahlak" ve "vicdan" gibi kavramların etkinliği hakkında ne düşünmektedir? 


\subsection{Araştırmanın Yöntemi}

Otorite kavramı, tıpkı sosyal bilimlerdeki diğer kavramlar gibi kolaylıkla ifade edilip açıklanamamaktadır. Bu nedenle her bir kavrama ve bu kavramın ilişkide olduğu diğer kavram ya da olgularla ilişkisine farklı bakış açıları getirilebilmektedir. Topateş (2014: 338) dinsel inançların otoriteyi etkilediğini, Yiğitceoğlu (2013: 129) kültür ile otorite arasında ilişki bulunduğunu, Yıldız (2000: 94) ise otoritenin alg1 ile yakından ilişkili olduğunu, kültürden kültüre farklılaşabileceğini ve bu nedenle her bir kültüre uygun ayrı bir otorite davranış ölçeği geliştirilmesi gerektiğini ifade etmiştir. Bu durum otoritenin içerisinde bulunulan toplumsal bağlama özgü karakterler taşıyabileceğini göstermektedir. Bu nedenle otorite ile yönetim arasındaki ilişkiye yönelik çalışmalarda toplumsal ve kültürel faktörlerin dikkate alınması gerektiği söylenebilir. Sosyal bağlamı göz önünde tutarak yapılan çalışmalarda ise yorumlayıcı yaklaşım ya da yöntemin kullanılması daha uygun görülmektedir. Ancak yorumların nicel veri ve analizlere dayalı olarak yapıldığında daha sağlıklı sonuçlara ulaşılabileceği ihmal edilmemelidir. Bundan dolayı bu çalışmada nicel verilerin yorumlayıcı yaklaşımla değerlendirilmesi yöntemi tercih edilmiştir. $\mathrm{Bu}$ nedenle çalışmanın yöntemi anket türünde betimleme yöntemi olarak tanımlanabilir.

\section{3. Örneklemin Seçimi}

Örneklemin belirlenmesinde, olasılığa dayalı olmayan örnekleme tekniklerinden "kolayda örnekleme" tekniği kullanılmıştır. Araştırma, yönetim otoritesinin en belirgin biçimde hissedildiği kamu iş örgütleriyle sınırlandırılmıştır' ${ }^{9}$. Örneklem olarak Hitit Üniversitesi Rektörlüğ̈̈ ve bağlı kuruluşlardaki idari personel ile Çorum valiliğine bağlı kamu idarelerinde çalışan personel seçilmiştir. Çorum ili merkezindeki kamu iş örgütlerinde yaklaşık $3.000 \mathrm{kamu}$ çalışanı vardır. Ayrıca, Çorum ili sınırları içerisinde faaliyet göstermekte olan Hitit Üniversitesi'nde de 390 personel olmakla beraber bunların yalnızca 168'i idari personel ve yaklaşık 30'u idari görevi olan akademik personeldir. Çalışmamızın içeriği itibariyle klasik hiyerarşi içerisinde bulunmayan akademik personele anket çalışması uygulanmamış, sadece idari ve idari görevi olan akademik personele uygulanmıştır. Hitit Üniversitesi Rektörlüğü merkez birimlerinde 80 idari çalışan, fakülte ve yüksekokul gibi bağlı birimlerde 76 idari çalışan ve ilin diğer kamu birimlerindeki 80 kamu çalışanı olmak üzere toplam 236 kamu personelinden veri toplanmış ve anketlerin tümü değerlendirmeye alınmıştır.

\subsection{Verilerin Toplanması ve Analizi}

Katılımcılara, ilk 6 sorusu demografik bilgileri içeren, diğer 34 sorusu yönetim, otorite ve yönetim-otorite ilişkisine bakış açılarını öğrenmeye yönelik toplam 40 soruluk anket formları elden dağıtılmıştır. Anket formu Yıldız (2000), Tuncer (1999) ve Yeşertener'in (1994) daha önceki çalışmalarında kullandıkları formlardan esinlenerek oluşturulmuştur. Elde edilen veriler SPSS programı yardımıyla istatistiksel tablolar haline dönüştürülerek değerlendirilmiş ve yorumlanmıştır.

Anket çalışmasında, "liste" soru ve "kategori" soru biçimleri ve nominal ölçme yöntemiyle yaş, cinsiyet, eğitim durumu gibi sosyo-demografik özelliklere ilişkin veriler elde edilmeye çalışılmıştır. Anketin 1'den 6'ya kadar olan soruları bu kapsamdadır. Elde edilen ölçüm değerleri için frekans dağılımı yapılmıştır. Anketteki 7'inci sorudan 31'inci soruya kadar

\footnotetext{
${ }^{9}$ Yiğitceoğlu (2013: 105) çalışmasında kamu işyerlerinde özel sektör örgütlerine kıyasla otoritenin daha belirgin olduğu sonucuna ulaştığını belirtmektedir.
} 
olan sorular "likert ölçeği" ile hazırlanmıştır. 5'li "likert ölçeği" nin kullanıldığg sorularda 5'den 1'e doğru aralık seviyesi ölçülmüştür. Anketin 32'den 40'a kadar olan soruları "liste soru" biçiminde hazırlanmış ve katılımcının düşüncesi, tercihi ya da beklentileri belirlenmeye çalışılmıştır.

Elde edilen veriler Frekans Dağglımı, Aritmetik Ortalama, Yüzde Oran, Ortalama Değer gibi tanımlayıcı istatistiklere dönüştürülmüş ve değişkenlerin birbirleri üzerindeki dağılımlarını gösteren çapraz tablolar oluşturulmuştur. Kategorik değişkenler arasındaki gözlenen frekans değerleri ile teorik olarak beklenen frekans değerlerinin karşılaştırmasını yapmak ve anlamlı bir farklılığın olup olmadığını tespit etmek için Ki-Kare testi uygulanmıştır. Birbirinden bağımsız grupların bağımlı bir değişkene ilişkin ölçümlerinin karşılaştırılarak iki dağılım arasında anlamlı bir fark olup olmadığını tespit etmek amacı ile Kruskal-Wallis testi yapılmıştır. Anket çalışmasında ulaşılan bulgular ile teorik kısımda betimsel analiz yöntemiyle elde edilen sonuçlar karşılaştırılarak yönetici - yönetilen ilişkileri ve otoritenin bu ilişki üzerindeki etkileri yorumlanmaya ve bazı çözüm önerileri getirilmeye çalışılmıştır.

\section{BULGULAR}

Bulgulara ilişkin yüzde oranları ifadelere katılıyorum ve kesinlikle katılıyorum ya da katılmıyorum ve kesinlikle katılmıyorum oranları toplanarak elde edilmiştir.

Araştırma sorusu-1: Kamu çalışanları otoriteyi ne olarak görmekte ya da nasıl algilamaktadır?

Ankete katılanlar arasında otoriteyi makam ve mevki olarak algilayanlar \%29, bilgi ve uzmanlık olarak algılayanlar \%79, karizmatik kişilik olarak algılayanlar \%38, ödül ve terfi yetkisi olarak görenler \%26, yasa ve yönetmelik olarak görenler ise $\% 41$ oranında çıkmıştır. Oysaki katılımcılar yöneticilerin emirlerine uyma nedeni olarak $\% 65$ ile ast-üst ilişkilerini birinci sırada göstermektedir. Yani emirlere uyma nedenleri ile otorite olarak görme nedenleri birbirinden farklıdır. Kamu iş yerlerinde makam ve mevki ile yasa ve yönetmeliğin otorite olarak görüldügü şeklindeki genel tespitin ${ }^{10}$ tam tersine, daha çok özel sektör iş yerlerinde otorite olarak görüldüğü düşünülen bilgi ve uzmanlık \%79 ile diğerlerine kıyasla oldukça yüksek çıkmıştır. Uzman, bilgili ve tecrübeli personele özel saygı duyarım ifadesine katılma oranı \%84 ile oldukça yüksektir ve bilgi ve uzmanlık otoritesindeki \%79 oranını teyit etmektedir.

Otoriteye ilişkin bazı tutumlar ile bağımsız kategorik değişkenler arasındaki ilişkiyi ölçmek için Ki-Kare testi yapılmıştır. Otoritenin makam ve mevki olduğuna katılma ile mesleki pozisyon arasında 0,197 düzeyinde anlamlı bir ilişki bulunamamıştır. Üst yöneticilerin beklenilenin aksine bu ifadeye yaklaşık \%83 oranla en çok katılmayan kesim olduğu görülmektedir. Bu ifadeye iş yeri tercihinde en önemli faktörün kariyer olduğunu belirtenler $\% 40$ ile en fazla katılanlar olmuştur. Fakat iş yeri tercih faktörleri ile ifadeye katılım arasında 0,090 düzeyinde anlamlı bir ilişki bulunamamıştır. İş yeri tercih nedenleri ile otorite bilgi ve uzmanlıktır ifadesine katılım arasında 0,141 düzeyinde, karizmatik kişiliktir ifadesine katılım arasında 0,865 düzeyinde, ödül ve terfi yetkisidir ifadesine katılım arasında 0,546 düzeyinde, yasa ve yönetmeliktir ifadesine katılım arasında 0,674 düzeyinde anlamlı ilişki bulunamamıştır. Otoritenin yasa ve yönetmelik olduğu ifadesine katılım ile mesleki pozisyon arasında 0,769 düzeyinde anlamlı bir ilişki bulunamamıştır. Bu ifadeye en çok hiyerarşinin en alt basamağında bulunan işçiler $\% 53$ oranla ve en üst basamağında bulunan üst yöneticiler $\% 50$ oranla katıldıklarını belirtmişlerdir.

\footnotetext{
10 Yeşertener çalışmasında, kamuda makam ve yasalara dayalı otoritenin, özel sektörde ise bilgisel otoritenin baskın olduğunu ifade eder (bkz: Yeşertener, 1994: 100)
} 
Araştırma sorusu-2: Kamu çalışanları otoritenin işlevleri hakkında ne düşünmektedir?

Ankete katılanlar otoritenin \%86 ile en fazla disiplin ve iş yapılmasını sağladığını fakat \%73 ile otoriteyi sağlamanın bütün sorunları çözmeyeceğini düşünmektedir. \%67'si ise otoriter yönetimlerin işlerin iyi yapılmasını sağlayamayacağı kanaatindedir. Otoritenin sembolik ifade ve uygulamalarla etkisini hissettirdiği düşüncesine ancak \%37'si katılmaktadır. Otoriter yönetimlerin her yerde her zaman işlerin iyi yapılmasını sağladığına kadınlar \%22 oranla katılırken, erkekler \%37 oranında katılmaktadırlar. Yapılan Ki-Kare testinde anlamlılık düzeyi 0,051 çıkmıştır. Yani bu ifadeye katılımda cinsiyet açısından anlamlı bir fark bulunamamıştır. Amir ya da yöneticilerin her türlü istek ya da talimatlarını sorgulamadan yerine getirmek gerekir ifadesine katılmama \%70'dir. Yapılan Kruskal-Wallis testinde çalışanların yaşları ile ifadeye katılım arasında 0,97 düzeyinde anlamlı bir ilişki bulunamamıştır.

Araştırma sorusu-3: Kamu çalışanları yöneticilerin otoriteyi kullanım biçimlerine ilişkin ne düşünmektedir?

Yöneticilerin tehdit ve korkutma yöntemi ile iş yaptırdıkları düşüncesine katılım \%22 ile oldukça azdır. Kadın ve erkek çalışanlar hemen hemen aynı \%50 oranında yöneticilerin iş gördürmede korku ve tehdit metodunu kullandıklarını düşünmektedirler. Ki-Kare testinde 0,288 düzeyinde ifadeye katılımla cinsiyet arasında anlamlı bir ilişki olmadığ 1 bulunmuştur. Yöneticilerin otoriteyi araç değil amaç olarak gördükleri ifadesine katılma oranı ise $\% 38$ ile düşük çıkmıştır. Yöneticilerin işin niteliğinden değil kendi kişisel takıntılarından dolayı gereksiz disiplin sağlamaya çalışır düşüncesine katılım \%38 oranındadır. Bu bulgulardaki en dikkat çekici sonuç, korku ve tehdit yoluyla iş yaptırma ifadesine katılımın oldukça düşük olmasıdır. Otoriteyi kullanım biçimi olarak \%31 otoriteyi kendinde toplama, \%25 yetkiyi kendinde birakarak sorumluluğu alt kademelere kaydırma, \%19 güç taşkınlığı, \%14 çıkar sağlama, \%5 yolsuzluk, $\% 4$ şiddet kullanma ve \%2 otoritenin amacı dışında kullanımını göstermiştir. Çıkar sağlama amacında olan yöneticilerin güç taşkınlığı ve şiddete başvurma eğilimlerinin yüksek olduğu düşüncesine katılım \%63'dür. Üst yöneticiler, çıkar sağlama davranışında olan yöneticilerin daha çok şiddete başvurduğu ifadesine $\% 50$ oranında katılırken, birim yöneticileri $\% 61$, şube yöneticileri $\% 75$ ve şefler $\% 79$ oranında katılmaktadırlar. Fakat mesleki pozisyon ile çıkar sağlayan yöneticilerin şiddete daha çok başvurduklarına katılma arasında 0,131 düzeyinde anlamlı bir ilişki görülmemektedir.

Araştırma sorusu-4: Kamu çalışanları otoritenin ne gibi sorunlar meydana getirdiğini düşünmektedir?

Ankete katılanlar bask1, korkutma, tehdit ve psikolojik şiddetin \%85 oranında motivasyonu azaltacağı, \%81 oranında verimi düşüreceği, \%73 oranında ise yöneticiye saygıyı azaltacağı, \%59 oranında örgüte bağlılığının azalacağı kanaatindeler.

Araştırma sorusu-5: Kamu çalışanları otorite kaynaklı sorunlara hangi yöntemlerin çözüm getirebileceğini düşünmektedir?

Otoriteyi yanlış kullanımın nedeni olarak yöneticilerin yeterince donanımlı, bilgili ve yetenekli olmadığı ifadesine ise katılım \%81 ile oldukça yüksektir. Bu ifadeye katılım ile eğitim seviyesi arasında 0,011 düzeyinde anlamlı bir ilişki vardır. Düşük eğitimlilerden yüksek eğitimlilere doğru bu ifadeye katılmama oranı düşüyor. İlkokul \%28,6; Ortaokul \%16,7 iken lise ve ön lisans \%10-11 civarındadır. Lisans mezunlarında bu oran \%6 ya düşmektedir. Yani eğitim düzeyi yükseldikçe bilgi, donanım ve yeteneğin önemini fark etme oranı da yükselmektedir. Ankete katılanlar \%41 ile çalışanların motivasyonlarının artırılmasını, \%22 ile iş ortamının iyileştirilmesini, \%19 ile ekonomik düzenleme yapılmasını, \%14 ile iş görenin güçlendirilmesini önermektedir. Fakat ankete katılanların otorite kaynaklı gördükleri sorunlar ile bunların çözümüne ilişkin önerileri arasında 0,080 düzeyinde anlamlı bir ilişki bulunamamıştır. 
Araştırma sorusu-6: Kamu çalışanları otorite kaynaklı sorunların çözümünde "ahlak" ve "vicdan" gibi kavramların etkinliği hakkında ne düşünmektedir?

Ankete katılanların ancak \%9'u, denetlenmeyen alanlarda kurallara uymakta tereddüt ederim ifadesine katılmaktadır. \%86 gibi yüksek bir oranda katılmama söz konusudur. Bu durum ahlaki ve vicdani etkinin söz konusu olduğu düşüncesini akla getirebildiği gibi anket aracılığıyla bunu dişarıya ifade etmekten çekinildiği ihtimalini de düşündürebilir. İş yaparken zorunluluk dışında ahlaki ve vicdani sorumluluk duyarım ifadesine katılımın \%94 ile yüksek bir oranda olması ilk tespiti doğrulamaktadır. Bu ifadeye katılım ile ücret, makam, takdir, prestij, rekabet, inanç, statü gibi çalışanları motive eden faktörler arasında 0,850 düzeyinde anlamlı bir fark bulunamamıştır. Yani motivasyon sebebi ne olursa olsun çalışanlar ahlaki ve vicdani sorumluluk hissettiklerini belirtmektedir. Bu ifadeye katılım ile otoriteyi bilgi ve uzmanlık olarak görenler arasında 0,000 düzeyinde anlamlı bir ilişki bulunmuştur. $\mathrm{Bu}$ oranlar otoritenin yukarıda bahsedilen olumsuz sonuçlarını telafi etmede bilgi ve uzmanlığa dayalı otoritenin yanında "ahlaki otoritenin" de kullanılması gerektiği şeklinde bir değerlendirme yapılmasına izin vermektedir. $\mathrm{Bu}$ değerlendirme ise çalışmanın teorik kısmında bahsedilen diğer yönetsel otoritelerin bıraktığı boşlukları doldurmada "ahlaki otoritenin" işlevsel olabileceği öngörüsüyle örtüşmektedir.

\section{TARTIŞMA VE SONUÇ}

Otorite, insan hayatının bütününü ilgilendiren ve etkileyen önemli bir olgudur. İnsanın doğuşuyla başlayan otoriteyle tanışıklık, ölümüne kadar bazen hafifleyen bazen de şiddetini artıran bir ayrılmazlık içerisinde devam eder. Bu ayrılmazlık bazen dostça bir tavır takınır, bazen de dayanılmaz acılar yaşatan bir düşmanlık hali alır. Fakat hiçbir zaman hayat devam ettikçe son bulmaz. Çocukluk evresinde bu ilişki anne-babayla kurulur. Ebeveynlerin dedikleri kesin ve tartışılmaz gerçeklerdir ve harfiyen yerine getirilmelidir. Çocuk bu ortam içerisinde ilk deneyimlerini kazanır. Sonra okul çağı gelir. Orada ebeveyn figürü öğretmenle yer değiştirir. Figür değişmiştir fakat işlev aynıdır. Öğretmenin yap dedikleri yapılır, yapma dedikleri yapılmaz. Aksi bir tutum, cezayı gerektirmektedir. Bu bilinir ve zamanla içselleştirilir. Artık evde ebeveynlerin, okulda ise öğretmenlerin doğruları çocuk için hayatın gerçekleridir. $\mathrm{Bu}$ gerçekliğe aykırı bir tutuma yeltenirken bile cezası hesap edilmeye başlanır. Bilinir ki bu davranışın muhakkak bir karşılığı vardır. Bu iki otorite figürünün dışında sosyal çevre olarak adlandırılan aile yakınları, oyun arkadaşlıkları, mahalle, çarşı, sokak ve diğer tüm insani ilişkiler "sosyal kontrol mekanizması" olarak işlev görür. Tarihin bilinmeyen bir anından beri süregelmekte olan ve bütün bu ilişkileri şekillendiren kurallar bellidir. Bunların dişına çıkabilmek ya da oyunu bozmak kolay affedilir bir durum değildir. Dışlanma ya da diğer bir deyişle "sosyal ölüm" bu tür davranışların en yaygın karşılığı olarak uygulanır. Otoritenin bu kaçınılmaz etkisi, kuralları yine bilinmeyen bir zamanda konmuş siyasi, ekonomik, kültürel ve estetik hayatta da devam eder. Oyunu bozmak ve kuralların dışına çıkmak zordur.

Hayatın belli kuralları olduğu gibi doğanın da belli kuralları vardır. İşleyiş bu kurallara göre devam eder. Doğa kurallarının değişmesi imkânsızdır. Hayat kurallarının değişmesi ise zordur. Hayatın değişmesi zor kuralları arasında belki de ilk sırada otorite vardır. Otorite, kaynağı ne olursa olsun insani ilişkilerin tümünde rastlanan bir olgudur. Bu olgu sahibine bir güç bahşeder. Bu güç amacına uygun ve doğru biçimde kullanılmadığ zaman birçok olumsuz sonuç doğurur. Otoritenin meydana gelmesinde en önemli etken eşitsizliktir. Eşitsizliğin kaynağı teknik, psikolojik, ekonomik, sosyolojik ve bilgiye sahip olma durumu olabilir. Fakat bir otoritenin var olabilmesi için biri diğerinden daha güçlü, daha avantajlı iki kişinin ya da olgunun varlığ gereklidir. Otorite hukuksal, yasal-demokratik ve yönetimsel olarak gruplandırılabilir. Yönetim açısından otoritenin çeşitleri, türleri ve kaynaklarına göre biçimleri farklıdır. Fakat bütün otorite çeşitleri meşruiyete dayanmak ister. Bu otoriteye muhatap olanların kabulleriyle 
ilgili bir durumdur. Otoritenin reddedilmesi bir nevi otoritenin ortadan kalkması ya da biçim değiştirerek güç, etki, iktidar gibi başka bir hal alması demektir. Otorite, yalnız bunlardan bir tanesi değil belki de bunların tümünü kapsamakla beraber meşru olarak kabul edilen bir olgu olarak tanımlanabilir.

Otoriteye sahip olanlar ya da otorite sahibi olanların otoriteyi amaçları dışında yanlış kullanmaları durumunda ortaya bazı yönetim sorunlarının çıkması kaçınılmazdır. $\mathrm{Bu}$ yanlış kullanımın sebepleri; otoritenin her zaman her yerde sorunları çözeceğine olan derin inanç ya da otoritenin bilinçli olarak kötüye kullanımı olabilir. Otoritenin kötüye kullanımı çıkar sağlama ya da bastırılmamış duyguların tatmini için güç taşkınlığı şeklinde olabileceği gibi sorumluluktan kurtulmak için otoriteyi kendinde toplayarak sorumluluğu dağıtma şeklinde de olabilir. Otoritenin kabulü, reddi ve kısmen kabulü halinde ortaya çıkabilecek farklı yönetim sorunlarının as1 temelinde yatan sebeplerden biri olarak, otorite sahiplerinin otoriteyi temsil edecek bilgi, yetenek, tecrübe, ehliyet ve liyakatte olmayışları gösterilebilir.

Otoriteye dayalı yönetim sorunlarının çözümünde yetki-sorumluluk denkliğinin sağlanması, yetkinin işlevsel dağılımı gibi yapısal çözüm yolları denenmekle beraber ekonomik düzenlemeler, personelin motivasyonunu artıracak tedbirler, iş ortamının iyileştirilmesi ve iş görenlerin güçlendirilmesi gibi klasik önlemlere de başvurulabilir. Ancak bütün bu yöntemlerin, kökleri insanlığın varoluşsal özelliklerinde bulunan otorite gibi derin bir kavramdan kaynaklanan sorunlara tamamen çözüm üretmesini beklemek zordur. Bu nedenle, insan davranışlarının ve karar alma iradesinin en önemli belirleyicisi olan ahlak kavramının yönetim sürecinde ki önemi bir kez daha ortaya çıkmış olur. Kuralları koyan ve denetleyen mekanizmanın bile kurallara uymadığı gerçeği göz önünde bulundurulursa, hem denetleyici hem de uygulayıcı bakımından ahlaki davranışın sorunsuz bir yönetim için nasıl bir anlam taşıdığı görülecektir.

Çalışmanın hem teorik hem de anket araştırması kısmında görülmektedir ki, yönetim sorunlarının temelinde "insan faktörü" yer almaktadır. İyi eğitilmemiş, gerekli donanım ve birikimden yoksun, yöneticilik kabiliyet ve gereklerine sahip olmayan, ehliyet ve liyakatten uzak kişilerin sorumluluk mevkilerinde oluşu yönetim sistemlerinin en büyük sorunlarının başında gelmektedir. İşinin gereği olan niteliklere sahip olmayan bir çalışan ve yöneticinin var olduğu bir iş örgütünde sorunların ortaya çıkması kaçınılmazdır. Aynı zamanda bu nitelikleri sadece maddi göstergelere indirgemek de sorunun bir kısmını görmezlikten gelmek demektir. Sorunun bir de ahlaki boyutu vardır. Bu boyut tamamlanmadığ1 sürece, sistemin gereklerini konulan kurallar çerçevesinde uygulayacak kişilerin art niyetli olması ve bunları belirli kurallar çerçevesinde denetleyecek olanların da aynı art niyeti taşıması halinde, hem sistemin hem de kuralların hiçbir anlamı kalmayacaktır.

\section{KAYNAKÇA}

Arendt, H. (2004). Geçmişle Gelecek Arasında: Otorite Nedir? (Çev. B.Sina Şener), İstanbul: İletişim Yayınları.

Aron, R. (2007). Sosyolojik Düşüncenin Evreleri, (Çev. Korkmaz Alemdar), İstanbul: Kırmızı Yayınları, 7.Baskı.

Aydoğdu, S. (2001). Örgütlerde Yönetsel Yetkenin Ast-Üst İlişkilerinin İyileştirilmesi Yönünden Analiz Edilmesi, Basılmamış Yüksek Lisans Tezi, Kocaeli Üniversitesi Sosyal Bilimler Enstitüsü, Kocaeli.

Adler, A. (1997). Insanı Tanıma Sanatı, (Çev. Şelale Başar), İstanbul: Dergâh Yayınları.

Başaran, İ. E. (2004). Yönetimde İnsan İlişkileri, Ankara: Nobel Yayınları, 3.Basım.

Berberoğlu, G. N. (1985). Otorite ve Karizma, Anadolu Üniversitesi İİBF Dergisi, 3(1), 131-142.

Bayrak, S. (2001). Yönetimde Bir İhmal Konusu Olarak Güç ve Güç Yönetimi-II-, Süleyman Demirel Üniversitesi İIBB Dergisi, 6(1), 23-42.

Blau, P. M. (1963). Critical Remarks on Weber's Theory of Authority, American Political Science Review, (57)2, 305316. 
Bröckling, U. (2008). Disiplin: Askeri İtaat Üretiminin Sosyolojisi ve Tarihi, (Çev. Veysel Atayman) İstanbul: Ayrıntı Yayınları.

Canetti, E. (2006). Kitle ve İktidar, (Çev. Gülşah Aygen) İstanbul: Ayrıntı Yayınları.

Çam, E. (2005). Siyaset Bilimine Giriş, İstanbul: Der Yayınları.

Çınar, A. (2006). Kimin Otoritesi? Hangi Otorite? Uludağ Üniversitesi İlahiyat Fakültesi Dergisi, 15(1), 232-243.

Dahl, R. A. (2002). 21 'nci Asırda Siyasi Eşitlik, (Çev. M. Kutlu ve A.G. Tunal1), Türkiye ve Siyaset Dergisi, (9)10, 73-83.

Dönmezer, S. (1999). Toplumbilim, İstanbul: Beta Yayınları.

Dereli, T. (1985). Organizasyonlarda Davranış, İstanbul: Okan Yayınları.

Duverger, M. (2007). Siyaset Sosyolojisi, (Çev. Şirin Tekeli) İstanbul: Varlık Yayınları.

Eroğlu, F. (2009). Yönetici Yetersizliği ve Güç Taşkınlı̆̆l, http://www.turkocagi.org.tr/modules.php/Makale. 08.04.2009

Eroğlu, F. ve İrmiş, A. (2004). Yönetim Krizlerine Karşı Yönetim Ahlakının Yeniden İnşası, Türkiye Günlüğü Dergisi, 78, 104-107.

Foucault, M. (2005). Özne ve İktidar, (Çev. Işık Ergüden ve Osman Akınhay) İstanbul: Ayrıntı Yayınları.

Fromm, E. (2006). Sağlıklı Toplum, (Çev. Y. Salman ve Z. Tanrısever) İstanbul: Payel Yayınları.

Giddens, A. (2008). Sosyoloji, (Yay.Haz. Cemal Güzel) İstanbul: Kırmızı Yayınları.

Güngör, E. (2005). Ahlak Psikolojisi ve Sosyal Ahlak, İstanbul: Ötüken Neşriyat, 3.Basım.

Haldun, İ. (2005). Mukaddime, Cilt:1-2, (Yay.Haz. Süleyman Uludağ) İstanbul: Dergâh Yayınları.

Heimsoeth, H. (2007). Kant'ın Felsefesi, (Çev. Takiyyettin Mengüşoğlu) Ankara: Doğu Batı Yayınları, 3.Basım.

Hodgkinson, C. (2008). Yönetim Felsefesi, Çev. Ed. İ. Anıl ve B. Doğan) İstanbul: Propedia Yayınları, 1.Basım.

Jondt, F.E. (1998). Yönetim Sorunlarına Etkili Çözümler, (Çev. Levent Akın ve Vedat G. Diker) İstanbul: Hayat Yayınları.

Jouvenel, B. (1997). İktidarın Temelleri, (Çev. Nejat Muallimoğlu) İstanbul: Birleşik Yayınları.

Kağıtçıbaşı, Ç. (2006). Yeni İnsan ve İnsanlar, İstanbul: Evrim Yayınları.

Kapani, M. (2008). Politika Bilimine Giriş, Ankara: Bilgi Yayınları.

Kılıç, R. (1998). Erol Güngör'ün Ahlak Anlayışı, Felsefe Dünyası, 27, 38-53 http://www.felsefelk.com/felsefedunyasi/27-1998/27-038pdf, 13.01.2009.

Kışlalı, A. T. (2008). Siyaset Bilimi, Ankara: İmge Yayınevi.

Krech, D. \& Crutchfield R.S. (2007). Sosyal Psikoloji, (Çev. Erol Güngör) İstanbul: Ötüken Neşriyat.

Koçel, T. (2005). İşletme Yöneticiliği, İstanbul: Arıkan Yayınları, 10.Basım.

Kojave, A. (2007). Otorite Kavramı, (Çev. Murat Erşen) İstanbul: Bağlam Yayıncılık.

Küçükalp, D. (2008). Toplumsal Organizmanın Bir Hastalığı: Otorite, İşgüç Dergisi, 3(1) http://www.isgucdergi.org/index.php?cilt=3 22.11.2008.

Le Bon, G. (2005). Kitleler Psikolojisi, (Yay. Haz. Yunus Ender) İstanbul: Hayat Yayınları.

Lipson, L. (1973). Politika Biliminin Temel Sorunları, (Çev. Tuncer Karamustafaoğlu) Ankara: Ankara Üniversitesi Yayınları.

Lukes, S. (2002). İktidar ve Otorite, (Çev. Sabri Tekay), İçinde Bottamare, T. \& Nisbet, R. (Der) Sosyolojik Çözümlemenin Tarihi, Ankara: Ayraç Yayınları.

Mendel, G. (2005-a). Bir Otorite Tarihi: Süreklilikler ve Değiş̧iklikler, (Çev. Işık Ergüden) İstanbul: İletişim Yayınları.

Mendel, G. (2005-b). Son Sömürge Çocuk: Sosyo-Psikanaliz Açıdan Otorite, (Çev. Hüsen Portakal) İstanbul: Cem Yayınları.

Russell, B. (2004). İktidar, (Çev. Göksel Zeybek) İzmir: İlya Yayınları. 
Sanford, N. (2006). Otoriteryen Kişilik ve Uyma, (Çev. M.R. Gürkaynak ve V. Batmaz) İstanbul: Salyangoz Yayınları. Sennett, R. (2005). Otorite, (Çev. Kamil Durand) İstanbul: Ayrıntı Yayınları.

Swingwood, A. (1998). Sosyolojik Düşüncenin Kısa Tarihi, (Çev. Osman Akınhay) Ankara: Bilim ve Sanat Yayınları.

Şahin, H. (1999). Liderlik - Yöneticilik Ayrımı, Basılmamış Yüksek Lisans Tezi, Marmara Üniversitesi Sosyal Bilimler Enstitüsü, İstanbul.

Şimşek, M.Ş. (1998). Yönetim ve Organizasyon, Konya: Damla Yayınları.

Topateş, H. (2014). Türkiye'de Çalışma Illişkilerinde Dinsel Otorite ve Emek Disiplini, Basılmamış Doktora Tezi, Ankara Üniversitesi Sosyal Bilimler Enstitüsü, Ankara.

Touraine, A. (2007). Modernliğin Eleştirisi, (Çev. Hülya Tufan) İstanbul: Yapı Kredi Yayınları.

Tuncer, A. (1999). Yönetim Tarzlarına Göre Liderlerin Otorite ve Güç Kaynakları, Basılmamış Yüksek Lisans Tezi, Dokuz Eylül Üniversitesi Sosyal Bilimler Enstitüsü, İzmir.

Yeşertener, C. (1994). Yönetsel Otoritenin Analizi, Basılmamış Yüksek Lisans Tezi, Atatürk Üniversitesi Sosyal Bilimler Enstitüsü, Erzurum.

Yıldız, H. (2000). Otoriteye Yönelik Davranış Ölçeği, Dilsel Eşdeğerlik ve Güvenilirlik Çalışması, Basılmamış Yüksek Lisans Tezi, Marmara Üniversitesi Eğitim Bilimleri Enstitüsü, İstanbul.

Yiğitceoğlu, E. (2013). Türk Örgüt Kültüründe Otorite ve Otorite İlişkileri, Basılmamış Yüksek Lisans Tezi, Mersin Üniversitesi Sosyal Bilimler Enstitüsü, Mersin. 